DOI: http://dx.doi.org/10.33846/ghs5406

\title{
Hubungan Tingkat Pengetahuan Ibu dan Pemberian ASI Ekslusif dengan Status Gizi Anak Usia 7-11 Bulan di Dusun Kalapa Dua Desa Kairatu Tahun 2019
}

\author{
Rahma Tunny (koresponden) \\ (IImu Kesehatan Masyarakat; STIKes Maluku Husada; rahmatunny@gmail.com) \\ Epi Dusra \\ (IImu Kesehatan Masyarakat; STIKes Maluku Husada; dusraephy@gmail.com) \\ Mentari Yunita \\ (IImu Kesehatan Masyarakat; STIKes Maluku Husada; mentariyunita@gmail.com) \\ Debora Rumaella \\ (IImu Kesehatan Masyarakat; STIKes Maluku Husada; deborar@gmail.com)
}

\section{ABSTRAK}

Perkembangan dan pertumbuhan merupakan proses yang terjadi pada setiap makhluk ciptaan Tuhan. Masa ini ditandai oleh pertumbuhan dan perkembangan yang cepat serta perubahan dalam kebutuhan gizi. Tujuan umum dalam penelitian ini adalah untuk mengetahui hubungan tingkat pengetahuan ibu dan tinggkat pemberian ASI dengan Status Gizi Anak Di Dusun Kalapa Dua Kabupaten Seram Bagian Barat Tahun 2019. Desain penelitian ini menggunakan rancangan penelitian survey deskriptif analitik dimana peneliti ini bertujuan untuk mengetahui hubungan tingkat pengetahuan ibu dan pemberian ASI dengan status gizi pada bayi usia 7-11 bulan di dusun kelapa dua desa Kairatu. Hasil penelitian bahwa tidak ada hubungan pengetahuan dengan status gizi pada balita di dusun kelapa 2 desa kairatu kecamatan kairatu kabupaten seram bagian barat tahun 2019, Tidak ada hubungan pemberian ASI Ekslusif dengan status gizi pada balita di Dusun Kelapa 2 Desa Kairatu Kecamatan Kairatu Kabupaten Seram Bagian Barat tahun 2019

Kata kunci: pengetahuan; ASI esklusif; status gizi

\section{PENDAHULUAN}

\section{Latar Belakang}

Perkembangan dan pertumbuhan merupakan proses yang terjadi pada setiap makhluk ciptaan Tuhan. Masa ini ditandai oleh pertumbuhan dan perkembangan yang cepat serta perubahan dalam kebutuhan gizi. Pertumbuhan badan terjadi maksimal pada tahun pertama kehidupan (1) Salah satu upaya meningkatkan perkembangan bayi adalah dengan pemberian ASI Eksklusif. Air Susu Ibu merupakan faktor lingkungan dan kebutuhan asuh yang mengandung nutrisi terbaik bagi bayi karena ASI mengandung semua zat gizi dengan jumlah dan komposisi yang ideal serta sifat ASI yang sangat mudah diserap oleh tubuh bayi sangat bermanfaat untuk membantu pertumbuhan dan perkembangan bayi yang optimal serta melindungi terhadap berbagai penyakit. (2)

Hubungan/ masalah gizi buruk dan ASI Ekslusif disebabkan oleh pengetahuan ibu dan pengetahuan pada dasarnya adalah hasil dari tahun yang terjadi setelah orang melakukan pengindraan terhadap suatu objek tertentu melalui panca indra manusia, yakni indra penglihatan, pendengaran, penciuman, rasa dan raba. Sebagian besar pengetahuan diperoleh melalui mata dan telinga. Perilaku kesehatan dipengaruhi pula oleh pengetahuan sebagai faktor predisposisi. Jika pengetahuan tentang ASI Eksluisif baik diharapkan pula pada akhirnya perilaku terhadap pemberian ASI Ekslusif juga baik. ${ }^{(3)}$

\section{Tujuan Penelitian}

Tujuan umum dalam penelitian ini adalah untuk mengetahui hubungan tingkat pengetahuan ibu dan tinggkat pemberian ASI dengan Status Gizi Anak di Dusun Kalapa Dua Kabupaten Seram Bagian Barat Tahun 2019.

\section{METODE}

Desain penelitian ini menggunakan rancangan penelitian survey deskriptif analitik dimana peneliti ini bertujuan untuk mengetahui hubungan tingkat pengetahuan ibu dan pemberian ASI dengan status gizi pada bayi usia 7-11 bulan di Dusun Kelapa Dua Kairatu. Populasi dalam penelitian 
ini adalah kelompok ibu-ibu yang mempunyai bayi yang berumur usia 7-11 bulan, berdasarkan data dari bidan Kairatu jumlah ibu yang mempunyai bayi di usia 7-11 bulan sebanyak 32 orang.

\section{HASIL}

\section{Hasil Univariat}

Pengetahuan ibu dengan statuz gizi

Tabel 1. Distribusi Responden Berdasarkan Pengetahuan Ibu Di Dusun Kelapa 2 Kec.Kairatu Kab.Seram Bagian Barat Tahun 2019

\begin{tabular}{|c|c|c|}
\hline Pengetahuan & $\mathrm{n}$ & $\%$ \\
\hline Baik & 1 & 3,5 \\
\hline Cukup & 4 & 12,5 \\
\hline Kurang & 27 & 84,4 \\
\hline Jumlah & 32 & 100 \\
\hline
\end{tabular}

Berdasarkan tabel 1 diketahui bahwa responden dengan pengetahuan baik sebanyak 1 orang dengan persen $(3,5 \%)$ dan untuk pengetahuan cukup sebanyak 4 orang dengan persen sebanyak $(12,5 \%)$ dan untuk pengetahuan kurang sebanyak 27 orang $(84,4 \%)$.

\section{Pemberian Asi ekslusif dengan status gizi}

Tabel 2. Distribusi Responden Berdasarkan Pemberian Asi Ekslusif Ibu Di Dusun Kelapa 2 Kec.Kairatu Kab.Seram Bagian Barat Tahun 2019

\begin{tabular}{|l|c|c|}
\hline Pemberin ASI & $\mathrm{n}$ & $\%$ \\
\hline Ekslusif & 15 & 43,8 \\
\hline Tidak Ekslusif & 18 & 56,2 \\
\hline Jumlah & 32 & 100 \\
\hline
\end{tabular}

Berdasarkan tabel 2 diketahui bahwa dari 32 responden yang diteliti dengan pemberian Asi yang baik sebanyak 14 orang dengan persen sebesar $(43,8 \%)$ dan yang tidak baik sebanyak 18 orang dengan persen sebanyak $(56,2 \%)$.

\section{Status Gizi Anak}

Tabel 3. Distribusi Responden Berdasarkan Status Gizi Di Dusun Kelapa 2 Kec.Kairatu Kab.Seram Bagian Barat Tahun 2019

\begin{tabular}{|l|c|c|}
\hline Status Gizi & $\mathrm{n}$ & $\%$ \\
\hline Gizi Baik & 28 & 87,5 \\
\hline Gizi Kurang & 4 & 12,5 \\
\hline Jumlah & 32 & 100 \\
\hline
\end{tabular}

Berdasarkan tabel 3 diketahui bahwa dari 32 responden yang diteliti yang mempunyai balita dengan kondisi status gizi yang paling banyak adalah gizi baik mencapai 28 orang $(87,5 \%)$, sedangkan gizi kurang sebanyak 4 orang (12,5\%).

\section{Hasil Bivariat}

Hubungan Pengetahuan dengan status gizi pada balita

Berdasarkan hasil tabel 4 diatas dapat diketahui bahwa dari 32 responden yang diteliti yang mempunyai pengetahuan baik tetapi mengalami status gizi baik sebanyak 1 orang (100\%), dan yang mengalami gizi kurang sebanyak 0 orang $(0,0 \%)$, dan yang mengalami dan dari 32 responden yang mempunyai pengetahuan cukup namun mengalami status gizi baik sebanyak 3 orang $(75,0 \%)$, dan 
yang mengalami gizi kurang sebanyak 1 orang $(25,0 \%)$, dan dari 32 responden yang mempunyai pengetahuan kurang namun mengalami status gizi baik sebanyak 24 orang $(88,9 \%)$, dan yang mengalami gizi kurang sebanyak 3 orang $(11,1 \%)$.

Tabel 4. Responden Berdasarkan Hubungan Pengetahuan Dengan Status Gizi pada Balita di Dusun Kelapa 2 Kec.Kairatu Kab.Seram Bagian Barat Tahun 2019

\begin{tabular}{|c|c|c|c|c|c|c|c|}
\hline \multirow{2}{*}{ Pengetahuan } & \multicolumn{4}{|c|}{ Status Gizi } & \multicolumn{2}{|c|}{ Total } & \multirow{2}{*}{$\mathrm{P}$} \\
\cline { 2 - 7 } & \multicolumn{2}{|c|}{ Gizi Kurang } & \multicolumn{2}{|c|}{ Gizi Baik } & & & \\
\cline { 2 - 7 } & $\mathrm{n}$ & $\%$ & $\mathrm{n}$ & $\%$ & $\mathrm{n}$ & $\%$ & \\
\hline Baik & 1 & 10,0 & 0 & 0 & 1 & 100 & \multirow{3}{*}{0,683} \\
\hline Cukup & 3 & 75,0 & 1 & 25,0 & 4 & 100 & \\
\hline Kurang & 24 & 88,9 & 3 & 11,1 & 27 & 100 & \\
\hline Total & 28 & 87,5 & 4 & 12,5 & 32 & 100 & \\
\hline
\end{tabular}

Hubungan pemberian Asi ekslusif dengan status gizi pada balita

Tabel 5. Distribusi Responden Berdasarkan Hubungan Pemberian ASI Ekslusif Dengan Status Gizi Di Dusun Kelapa 2 Kec.Kairatu Kab.Seram Bagian Barat Tahun 2019

\begin{tabular}{|c|c|c|c|c|c|c|c|}
\hline \multirow{2}{*}{$\begin{array}{c}\text { Pemberian Asi } \\
\text { Ekslusif }\end{array}$} & \multicolumn{4}{|c|}{ Status Gizi } & \multicolumn{2}{|c|}{ Total } & \multirow{2}{*}{$\mathrm{P}$} \\
\cline { 2 - 8 } & Gizi Kurang & Gizi Baik & & & \\
\cline { 2 - 7 } & $\mathrm{n}$ & $\%$ & $\mathrm{n}$ & $\%$ & $\mathrm{n}$ & $\%$ & \\
\hline Ekslusif & 13 & 92,9 & 1 & 7,1 & 14 & 100 & \\
\hline Tidak Ekslusif & 15 & 83,3 & 3 & 16,7 & 18 & 100 & 0.403 \\
\hline Total & 28 & 87,5 & 4 & 12,5 & 32 & 100 & \\
\hline
\end{tabular}

Berdasarkan hasil tabel 5 diatas dapat diketahui bahwa dari 32 responden yang diteliti yang memiliki pemberian ASI Ekslusif tetapi mengalami status gizi baik sebanyak 13 orang (92,9\%), dan yang mengalami gizi kurang sebanyak 1 orang $(7,1 \%)$ dan dari 32 responden yang memiliki pemberian ASI tidak Ekslusif namun mengalami status gizi sebanyak 15 orang $(83,3 \%)$, dan yang mengalami gizi kurang sebanyak 3 orang $(16,7 \%)$

\section{PEMBAHASAN}

\section{Pengetahuan Ibu Dengan Status Gizi}

Pengetahuan adalah sesuatu yang diketahui berkaitan dengan proses pembelajaran. Proses pembelajaran ini dipengaruhi berbagai faktor dari dalam seperti motivasi dan faktor luar berupa sarana informasi yang tersedia serta keadaan sosial budaya. Secara garis besar domain tingkat pengetahuan mempunyai 6 tingkatan, meliputi mengetahui, memahami, menggunakan, menguraikan, menyimpukan, dan mengevaluasi. Peneliti berasumsi bahwa pengetahuan ibu akan status gizi sangatlah penting. Karena sangat berpengaruh bagi status gizi bayi, jika pengetahuan ibu tentang status gizi baik maka akan berpengaruh juga bagi bayi tersebut karena memiliki status gizi yang baik. (4), (5)

Status gizi adalah suatu ukuran mengenai tubuh seseorang yang dapat dilihat dari makanan yang di konsumsi dan penggunaan zat-zat gizi di dalam tubuh. Status gizi dibagi menjadi 3 kategori, yaitu status gizi kurang, gizi normal, dan gizi lebih. ${ }^{(6)}$

Pengetahuan terkait makanan dan zat gizi. Sikap dan perilaku ibu dalam memilih makanan yang akan dikonsumsi oleh balita dipengaruhi oleh berbagai faktor, diantaranya adalah tingkat pengetahuan seseorang tentang gizi sehingga dapat mempengaruhi status gizi seseorang tersebut. Pengetahuan gizi ibu yang kurang dapat menjadi salah satu penentu status gizi balita karena menentukan sikap atau perilaku ibu dalam memilih makanan yang akan dikonsumsi oleh balita serta pola makan terkait jumlah, jenis dan frekuensi yang akan mempengaruhi asupan makan pada bayi tersebut Pengetahuan gizi ibu dapat dipegaruhi oleh usia, pendidikan, pengetahuan, pekerjaan dan pendapatan. Selain itu, asupan makan pada balita juga dipengaruhi oleh budaya setempat yang juga dapat mempengaruhi pemilihan makanan oleh ibu. Oleh karena itu, jika seorang ibu memiliki pengetahuan gizi yang kurang maka asupan makanan yang akan diberikan kepada balita juga kurang tepat dan dapat mempengaruhi status balita tersebut. ${ }^{(7)}$ 
ASI Ekslusif

ASI adalah makanan terbaik dan alamiah untuk bayi. ASI merupakan suatu proses alamiah, namun sering ibu-ibu tidak berhasil menyusui atau menghentikan menyusui lebih dini dari yang semestinya. Banyak alasan yang dikemukakan oleh ibu-ibu antara lain, ${ }^{(8)}$ ibu merasa bahwa asinya tidak cukup atau asi tidak keluar pada hari-hari pertama kelahiran bayi. Sesungguhnya hal itu tidak disebabkan karena ibu tidak memproduksi asi yang cukup, melainkan karena ibu tidak percaya diri bahwa asinya cukup untuk bayinya. Disamping informasi tentang cara-cara menyusui yang baik dan benar belum menjangkau sebagian besar ibu. ${ }^{(9)}$

Pada dasarnya, ayah juga memiliki peran penting dalam proses menyusui karena bagi istri seorang suami adalah orang terdekat yang diharapkan selalu ada disisinya dan selalu siap untuk memberikan bantuan. Motivasi ibu akan bertambah jika mendapat dukungan dari suami untuk menambah kepercayaan dirinya untuk dapat melakukan pemberian ASI Eksklusif. Keinginan meniru adalah keinginan ibu untuk memberikan ASI Eksklusif yang didapat dari dukungan lingkungan sekitar yang dapat mempengaruhi niatnya. Teman atau orang terdekat merupakan sumber dorongan terkuat ibu dalam melakukan pemberian ASI Eksklusif (10), (11), (12)

Berdasarkan hasil penelitian, mayoritas responden mendukung terhadap keinginan meniru. Mayoritas responden dalam penelitian memilih pernyataan bahwa keberhasilan ibu, membuat ibu berkeinginan untuk memberikan ASI Eksklusif. Keinginan meniru ibu hamil di Kelurahan Magersari didapatkan dari hasil kebiasaan yang terjadi dalam keluarga, terutama ibu yang menurunkan perilaku kepada anaknya untuk menyusui dengan memberikan ASI Eksklusif. Kebiasaan yang dilakukan secara turun-temurun akan sangat mempengaruhi suatu perilaku.

\section{Hubungan Pengetahuan Ibu Dengan Status Gizi}

Pengetahuan merupakan domain yang sangat penting dalam membentuk tindakan seseorang (over behavior). Dari pengalaman dan penelitian terbukti bahwa perilaku yang didasari oleh pengetahuan akan lebih langgeng dari pada perilaku yang tidak didasari oleh pengetahuan. Penelitian Rogers (1947) dalam Soekidjo Notoatmodjo (2003:121) mengungkapkan bahwa sebelum orang mengadopsi perilaku baru (berperilaku baru). Berdasarkan hasil uji Chi-Squaretest berdasarkan nilai continuity correction diperoleh nilai $p=0,683$. hasil tersebut menunjukkan bahwa $0,683>0.05$ yang artinya Ho diterima dan Ha ditolak artinya tidak ada hubungan yang signifikansi antara pengetahuan ibu dengan statuz gizi balita.

\section{Hubungan Pemberian ASI Ekslusif Dengan Status Gizi}

ASI Ekslusif adalah pemberian ASI selama 6 bulan tanpa tambahan cairan lain, seperti susu formula, jeruk, madu, air, teh serta tanpa tambahan, makanan padat seperti pisang, bubur, susu, biskuit, kecuali vitamin dan mineral dan obat (Roesli, 2000). Selain itu pemberian ASI Ekslusif juga berhubungan dengan tindakan memberikan ASI kepada bayi berusia 6 bulan tanpa makanan dan minuman lain, kecuali sirup obat. Berdasarkan hasil uji Chi-Squaretest berdasarkan nilai continuity correction diperoleh nilai $p=0,403$. hasil tersebut menunjukkan bahwa $0,403>0.05$ yang artinya Ho diterima dan $\mathrm{Ha}$ ditolak artinya tidak ada hubungan yang signifikansi antara pemberian ASI Ekslusif dengan statuz gizi balita.

\section{KESIMPULAN}

Tidak ada hubungan pengetahuan dengan status gizi pada balita di Dusun Kelapa 2 Desa Kairatu Kecamatan Kairatu Kabupaten Seram Bagian Barat tahun 2019. Tidak ada hubungan pemberian ASI Ekslusif dengan status gizi pada balita di dusun kelapa 2 desa kairatu kecamatan kairatu kabupaten seram bagian barat tahun 2019.

\section{DAFTAR PUSTAKA}

1. Departemen Kesehatan RI, (2018). Pedoman Umum Pemberian Makanan Pendamping ASI (MPASI) Lokal.Jakarta.

2. Departemen Kesehatan RI. (2018). Laporan Hasil Riset Kesehatan Dasar Indonesia Tahun 2018. Depkes, Jakarta.

3. Fitri Mulianingsih, (2018). Hubungan Antara Pengetahuan Ibu Tentang Gizi Balita Dan Pola Makan Balita Terhadap Status Gizi Balita Di Kelurahan SrihardonoKecamatan Pundong. 
4. Kemenkes RI. Pedomen Gizi Seimbang. Kemenkes RI

5. Tri Mia, Desi sudardi dan Erfin,(2018). Hubungan Pengetahuan Sikap dan Praktik Pola Asuh lbu dengan Status Gizi Anak balita pada Keluarga Miskin Penerima DBLT Desa Kalibono Kecamatan Kaligesing Kabupaten Purworejo. Thesis. Universitas Diponegoro. Semarang.

6. N Puspasari, M. Andriani. Hubungan Pengetahuan Ibu tentang Gizi dan Asupan Makan Balita dengan Status Gizi Balita (BB/U) Usia 12-24 Bulan. DOI : 10.2473/amnt.v1i4.2017.369-378

7. Regar. Hubungan Kecukupan Asupan Energi dan Makronutrien dengan Status Gizi Anak Usia 57 Tahun di Kelurahan Kampung Melayu Jakarta Timur. Jurnal Kedokteran Universitas Indonesia 2013. [e-journal] 1 (3).

8. Liswati, E. M., 2016. Hubungan Karakteristik Ibu dengan Status Gizi Anak Balita yang Memiliki Jamkesmas di Desa Tegal Gizi Kecamatan Nogosari Kabupaten Boyolali [naskah publikasi]. Surakarta. Program Studi IImu Gizi Fakultas IImu Kesehatan Universitas Muhammadiyah Surakarta.

9. Nugroho, A. H. 2016. Program Perbaikan Gizi Masyarakat di Jawa Timur. Bidang PPKM Dinkes Provinsi Jawa Timur.

10. Jatmika, S. E. D. 2015. Norma Masyarakat Untuk Meningkatkan Niat lbu Hamil Dalam Memberikan ASI Eksklusif. Jurnal Kesehatan "Samodra IImu". [e-journal] 06(01): pp 51-55.

11. Kurniawati, D. 2014. Faktor Determinan yang Mempengaruhi Kegagalan Pemberian ASI Eksklusif pada Bayi Usia 6-12 bulan di Kelurahan Mulyorejo Wilayah Kerja Puskesmas Mulyorejo Surabaya

12. Dinah S, Dadang S, Tiurma S. 2017. Hubungan pengetahuan gizi, tingkat kecukupan zat gizi, dan aktivitas fisik dengan status gizi pada guru SMP. Jurnal Gizi Indonesia, 6 (1), 2017; Jurnal Gizi Indonesia (The Indonesian Journal of Nutrition) e-ISSN: 2338-3119, p-ISSN: 1858 , 6 (1), 2017 -4942 29 e-ISSN : 2338-3119, p-ISSN: 1858-4942 